\title{
A NOVEL APPROACH TO ENHANCE PERFORMANCE OF MULTILAYER COATED CARBIDE INSERT IN HARD TURNING
}

Flank wear of multilayer coated carbide $\left(\mathrm{TiN} / \mathrm{TiCN} / \mathrm{Al}_{2} \mathrm{O}_{3} / \mathrm{TiN}\right)$ insert in dry hard turning is studied. Machining under wet condition is also performed and flank wear is measured. A novel micro-channel is devised in the insert to deliver the cutting fluid directly at the tool-chip interface. Lower levels of cutting parameters yield the minimum flank wear which is significantly affected by cutting speed and feed rate. In comparison to dry and wet machining, insert with micro-channel reduces the flank wear by $48.87 \%$ and $3.04 \%$ respectively. The tool with micro-channel provides saving of about $87.5 \%$ in the consumption of volume of cutting fluid and energy.

\section{Introduction}

Industrial production and scientific research communities have shown immense interest in the machining of hard steel because it offers a number of potential advantages such as lower equipment costs, shorter setup time, high accuracy, fewer process steps, greater part geometry flexibility, and usually there is no need to use cutting fluid during turning of hard steel [1-2]. During hard machining, the cutting tools are subjected to severe forces and temperature which may cause tool wear and therefore, it is necessary to study and predict the tool wear for the effective design of cutting tools and determination of cutting conditions that will lead to the formulation of the tool change strategies. Numerous research studies pertaining to the tool wear of high per-

* Department of Mechanical Engineering, Diyala University, Diyala, Iraq (on leave to pursue Ph.D. from Jamia Millia Islamia, New Delhi, India)

${ }^{* *}$ Department of Mechanical Engineering, Jamia Millia Islamia (A Central University), New Delhi, India)

E-mails: suhakarim_10@yahoo.com,zakhanusm@yahoo.com, arshadnsiddiqui@gmail. com,noor_0315@yahoo.com 
formance cutting tool materials (ceramic, CBN, PCBN) have been carried out in the past, which has contributed greatly to the understanding of the factors responsible for the tool wear and also the tool wear mechanisms [3-13].

Available literature reveals studies focused on the investigation of the tool wear during turning of hard steel using coated carbide insert. Flank wear is the dominant wear for CVD coated tool, crater wear is dominant wear for PVD coated tool, abrasion and adhesion are dominant wear mechanisms for CVD coated tool, and adhesion and diffusion are dominant wear mechanisms for PVD coated tool [14]. Coated carbide tool materials have been reported to have longer tool life than CBN tools [15]. Suresh et al. [16] reported the following (i) the tool wear increases with the increase in cutting speed for all values of feed rates and the tool wear is sensitive to feed rate variations for all values of cutting speed, (ii) the tool wear is also sensitive to variations in depth of cut at lower values of cutting speed as compared to higher values, and (iii) the tool wear is minimum at low values of cutting speed, feed rate, depth of cut and machining time. Abrasion is the principal tool wear mechanism and cutting speed has the highest influence on tool wear followed by feed rate and depth of cut [17]. At low cutting speeds, the flank wear of the tools is due to adhesive, abrasive and fatigue fracture and the flank wear increases with increase in feed rate [18]. It appears from the literature review that study of the tool wear is important in case of hard turning. Thus, an attempt has been made in this paper also to investigate the effect of three hard turning parameters on the flank wear of a multilayer coated carbide tool insert. In addition, a new approach to improve performance of the insert with respect to reduction in (i) tool flank wear, (ii) cutting fluid consumption, and (iii) energy is also proposed in the paper.

\section{Experimental Details}

The following sections describe the details of the experimental procedure of the study.

\subsection{Materials and cutting parameters}

AISI 52100 alloy steel was used as workpiece material. The hardness of the as received alloy was 48 (HRC). The chemical composition of AISI 52100 is shown in Table 1. CNMG 120408-TN7105 hard multilayer coated carbide insert (TiN-TiCN- $\mathrm{AL}_{2} \mathrm{O}_{3}$-TiN) having nose radius of $0.8 \mathrm{~mm}$ was used as cutting tool. Table 2 lists the cutting parameters and their levels used in the present study. 
Table 1

Chemical composition of AISI 52100 alloy steel

\begin{tabular}{|c|c|c|c|c|c|c|c|c|c|}
\hline $\mathrm{C}$ & $\mathrm{Si}$ & $\mathrm{Mn}$ & $\mathrm{S}$ & $\mathrm{P}$ & $\mathrm{Ni}$ & $\mathrm{Cr}$ & $\mathrm{Mo}$ & $\mathrm{Cu}$ & $\mathrm{Fe}$ \\
\hline 0.98 & 0.28 & 0.39 & 0.024 & 0.023 & 0.141 & 1.302 & 0.081 & 0.042 & Rest \\
\hline
\end{tabular}

Table 2.

Cutting parameters and their levels

\begin{tabular}{|l|c|c|c|c|c|}
\hline \multicolumn{1}{|c|}{ Factors } & Symbol & Unit & Level-1 & Level-2 & Level-3 \\
\hline Cutting speed & $A$ & $\mathrm{~m} / \mathrm{min}$ & 100 & 175 & 250 \\
\hline Feed rate & $B$ & $\mathrm{~mm} / \mathrm{rev}$ & 0.1 & 0.16 & 0.22 \\
\hline Depth of cut & $C$ & $\mathrm{~mm}$ & 0.2 & 0.6 & 1 \\
\hline
\end{tabular}

\subsection{Tool Wear Measurement}

For tool wear measurement, nine experiments, as per the Taguchi's standard $\mathrm{L}_{9}$ orthogonal array, were performed on a centre lathe machine under dry condition. In each experiment, a fresh cutting tool insert was used for turning a fixed machining length of $300 \mathrm{~mm}$. The flank wear $\left(\mathrm{VB}_{\mathrm{B}}\right)$ of the tool insert was viewed and measured using Stereo-zoom microscope (brand: Focus; make: Japan). The width of flank wear was measured and the criterion of flank wear $\left(\mathrm{VB}_{\mathrm{B}}\right)$ was taken as $0.3 \mathrm{~mm}$ [19-21]. The flank wear measurement was repeated three times to minimise measurement error and average of the three measurements was taken to represent the average flank wear.

\subsection{Micro-Channel Setup}

A micro-channel was devised in the existing tool insert using a Wire-Electric Discharge Machine (WEDM) to ensure effective delivery of the cutting fluid directly at the tool-chip interface. A needle of $635 \mu \mathrm{m}$ and $318 \mu \mathrm{m}$ external and internal diameters respectively was used to construct the micro-channel and administer the cutting fluid at the chip interface. To fix the channel on the insert, a slot was machined on the rake surface of the insert at $2^{\circ}$ from it, as shown in the Fig. 1, using Wire - Electric Discharge Machine (WEDM). The cutting fluid was fed through a reservoir maintained at a differential head of $0.32 \mathrm{~m}$ as shown in Fig. 2. The angle of the channel, its exit location from the cutting edge and the differential head were established through extensive trial experiment. The cutting fluid jet exiting the channel supplied the cutting fluid at the interface at an estimated velocity $\left(v_{f}\right)$ of $2.5 \mathrm{~m} / \mathrm{s}$. The velocity was estimated using Eqn. 1 .

$$
v_{f}=\sqrt{2 g \Delta z},
$$

where $g$ is gravitational acceleration and is differential head. 


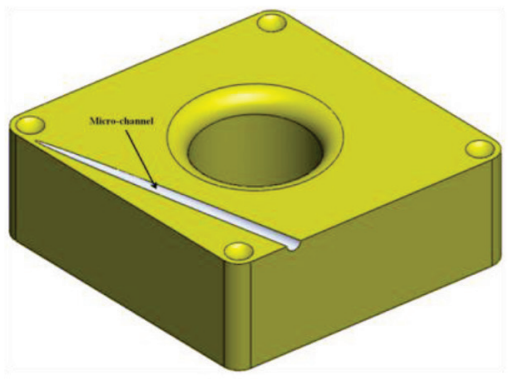

(a)
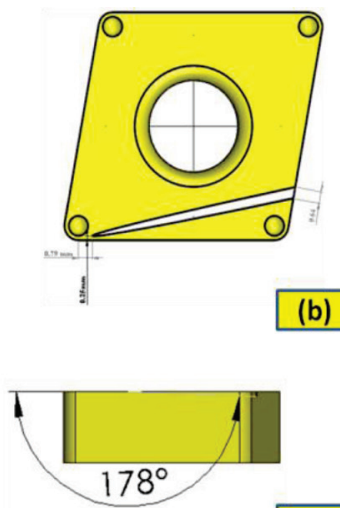

Fig. 1. The devised Micro-channel details: a) tool insert with micro-channel, b) dimensions of micro-channel, c) angle of the channel axis with rake surface

This micro-channel was devised on a fresh new tool insert with its nose polished with a suitable varnish to protect its cutting surface from damage due to spark produced during machining on wire EDM. The tool holder along with the insert was fixed on the wire EDM machine table and the machine was run to cut a circular slot of $644 \mu \mathrm{m}$ diameter. Into this slot, the micro-channel was fixed with glue. The tail end of the micro-channel was connected to the reservoir through flexible tuning, as shown in Fig. 2, through which cutting fluid was delivered to the tool-chip interface during machining. The schematic of the insert with micro-channel is shown in Fig. 3.

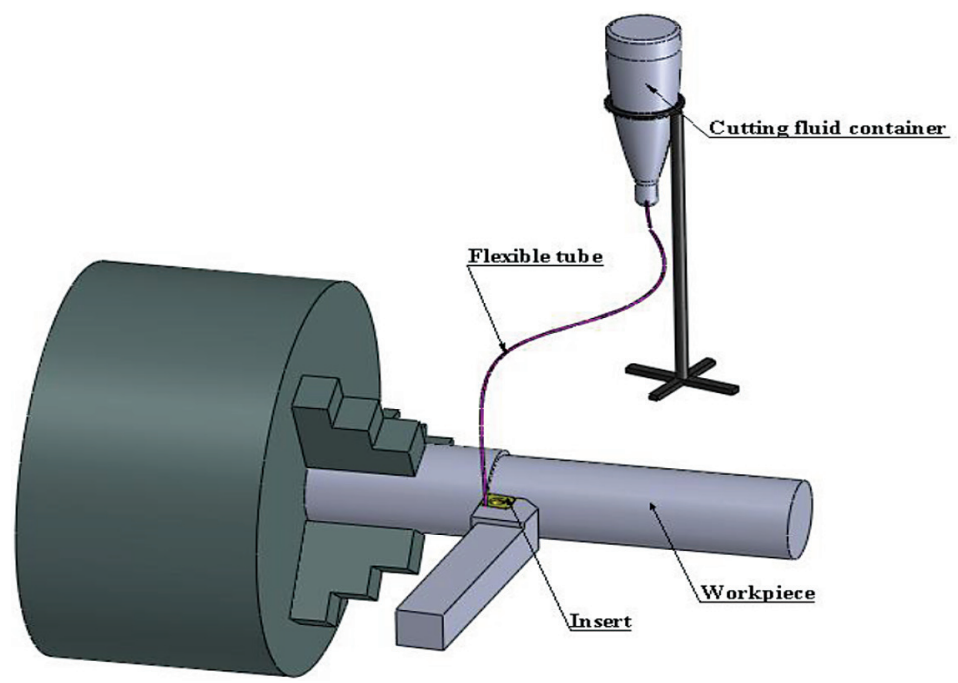

Fig. 2. The schematic of the micro-channel setup with the cutting fluid reservoir 


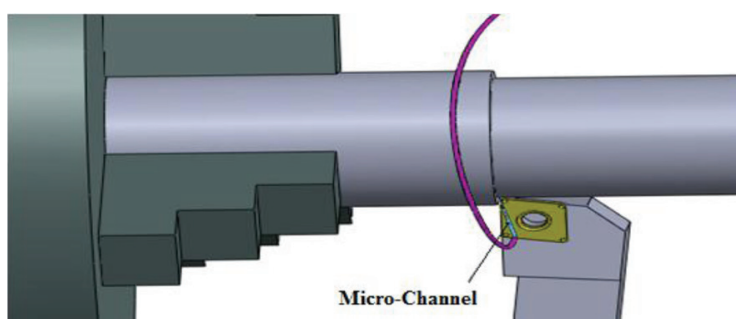

Fig. 3. The schematic of the micro-channel with flexible tubing

\section{Experimental Design}

The Taguchi method provides an effective experimental design with reduced number of experiments for conducting experiments and subsequent data analysis. Due to the advantages offered by this method, researchers have used this method to study tool wear [20, 22-24]. In the present study, the Taguchi design of experiments was used to investigate the effect of the cutting parameters on the tool flank wear $\left(\mathrm{VB}_{\mathrm{B}}\right)$. The lower-the-better criterion for $\mathrm{VB}_{\mathrm{B}}$ was chosen to calculate the $\mathrm{S} / \mathrm{N}$ ratio since low value of the tool wear is required. The $\mathrm{S} / \mathrm{N}$ ratio was calculated by using Eqn. (2).

$$
\mathrm{S} / \mathrm{N}=-10 \log \sum_{i=1}^{n} y_{i}^{2} .
$$

\section{Results and Discussion}

The following sections describe the results of the study. Further, the results obtained are also discussed.

\subsection{Statistical Analysis of Tool Wear under Dry Condition}

The tool inserts were used to machine over a machining length of $300 \mathrm{~mm}$ in each experiment and flank wear was measured. Three typical images of the worn out tool with flank wear at the tool tip for experiment number 2, 4, and 6 are shown in Fig. 4 (a), (b), and (c) respectively. Abrasion is found to be the principal wear mechanism observed from the images of tool tip because of existence of hard particles (chromium) in the workpiece. Additionally, no premature tool failure was observed and machining was steady using multilayer coated carbide insert. Table 3 shows the $\mathrm{L}_{9}$ orthogonal array along with the measured values tool flank wear and the corresponding signal-to-noise $(\mathrm{S} / \mathrm{N})$ ratio. It can be observed from Table 3 that the flank wear values remain within recommended limit of 0.3 $\mathrm{mm}$, when cutting is performed under the studied range of cutting parameters. 


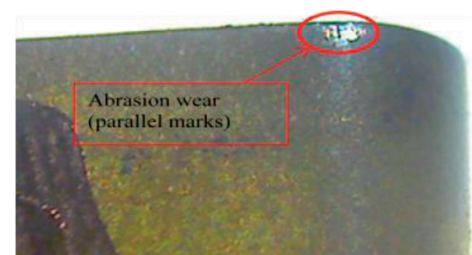

(a) Run 2

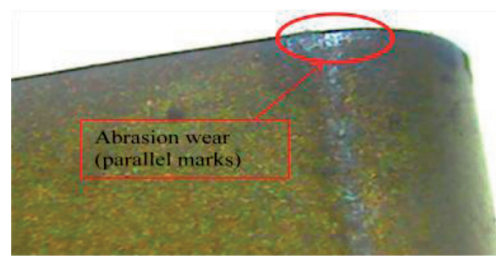

(b) Run 4

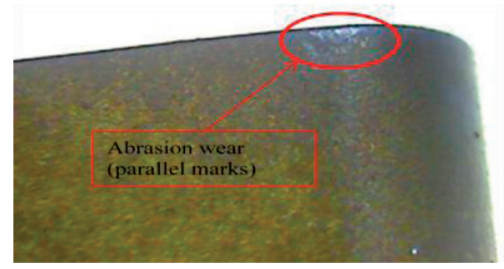

(c) Run 6

Fig. 4. Images of worn out tool with flank wear

Table 3.

Experimetal results and corresponding $\mathrm{S} / \mathrm{N}$ ratio

\begin{tabular}{|c|c|c|c|c|c|}
\hline \multirow{2}{*}{ Run } & \multicolumn{3}{|c|}{ Cutting parameters } & \multicolumn{2}{c|}{ Response parameter } \\
\cline { 2 - 6 } & $A$ & $B$ & $C$ & $\mathbf{V B}_{\mathbf{B}}$ & S/N ratio \\
\hline 1 & 100 & 0.10 & 0.2 & 0.04094 & 27.75704 \\
\hline 2 & 100 & 0.16 & 0.6 & 0.05263 & 25.57533 \\
\hline 3 & 100 & 0.22 & 1.0 & 0.08187 & 21.73750 \\
\hline 4 & 175 & 0.10 & 1.0 & 0.07649 & 22.32791 \\
\hline 5 & 175 & 0.16 & 0.2 & 0.08007 & 21.93060 \\
\hline 6 & 175 & 0.22 & 0.6 & 0.09975 & 20.02174 \\
\hline 7 & 250 & 0.10 & 0.6 & 0.06725 & 23.44615 \\
\hline 8 & 250 & 0.16 & 1.0 & 0.08772 & 21.13803 \\
\hline 9 & 250 & 0.22 & 0.2 & 0.09872 & 20.11190 \\
\hline
\end{tabular}

The mean $\mathrm{S} / \mathrm{N}$ ratio at each level of cutting parameters was obtained by averaging $\mathrm{S} / \mathrm{N}$ ratios corresponding to each level of the cutting parameters. For example: mean $\mathrm{S} / \mathrm{N}$ ratio for cutting speed at level 1 is calculated by averaging the $\mathrm{S} / \mathrm{N}$ ratios for the experiment numbers 1, 2 and 3 respectively. Similarly, the mean $\mathrm{S} / \mathrm{N}$ ratio for each level of other cutting parameters was also computed. Table 4 shows the mean $\mathrm{S} / \mathrm{N}$ ratio at each level of the cutting parameters. In addition, Table 4 also shows the mean $\mathrm{S} / \mathrm{N}$ ratio for all nine experiments. The analysis of variance (ANOVA) was conducted to study the significance of cutting parameters on flank wear based on their P-value and F-value at 5\% level of significance. The ANOVA results are shown in Table 5. It is concluded from Table 5 that the cutting speed, and feed rate significantly affect flank wear as $\mathrm{F}$ calculated value is more than the tabulated $F$ value $\left(\mathrm{F}_{0.05,(2,2)}=19.00\right)$. Depth of 
cut does not have significant effect on flank wear. The reason may be attributed to the increased length of contact between the tool and workpiece when depth of cut increases. This enables the improved heat flow from the cutting zone and consequently has negligible effect on the wearing process.

Table 4.

Response table mean $\mathrm{S} / \mathrm{N}$ ratio for flank wear

\begin{tabular}{|l|c|c|c|c|c|}
\hline Cutting parameters & Level-1 & Level-2 & Level-3 & Max-Min & Rank \\
\hline A & 25.02 & 21.43 & 21.57 & 3.60 & 2 \\
\hline B & 24.51 & 22.88 & 20.62 & 3.89 & 1 \\
\hline C & 23.27 & 23.01 & 21.73 & 1.53 & 3 \\
\hline Total mean S/N ratio & $=22.6718$ & & & & \\
\hline
\end{tabular}

Table 5.

ANOVA results for flank wear $\left(\mathrm{VB}_{\mathrm{B}}\right)$

\begin{tabular}{|l|c|c|c|c|c|c|}
\hline \multicolumn{1}{|c|}{ Source } & DF & SS & MS & F & P & Remarks \\
\hline A & 2 & 24.9116 & 12.4558 & 46.00 & 0.021 & Significant \\
\hline B & 2 & 22.8567 & 11.4283 & 42.21 & 0.023 & Significant \\
\hline C & 2 & 4.0489 & 2.0245 & 7.48 & 0.118 & \\
\hline Residual Error & 2 & 0.5415 & 0.2708 & & & \\
\hline Total & 8 & 52.358 & & & & \\
\hline
\end{tabular}

Figure 5 depicts the main effect plot for $\mathrm{S} / \mathrm{N}$ ratio. It can be seen from Fig. 5 that the optimal combination of the cutting parameters for flank wear is $A_{1} B_{1} C_{1}$, i.e., at cutting speed $(A)$ at $100 \mathrm{~m} / \mathrm{min}$, feed rate $(B)$ at $0.1 \mathrm{~mm} / \mathrm{rev}$, and depth of cut $(C)$ at $0.2 \mathrm{~mm}$. Fig. 6 shows the normal probability plot of the residuals for the tool flank wear and it reveals that the residuals either fall on a straight line or are very close to the line implying that the errors are distributed normally.

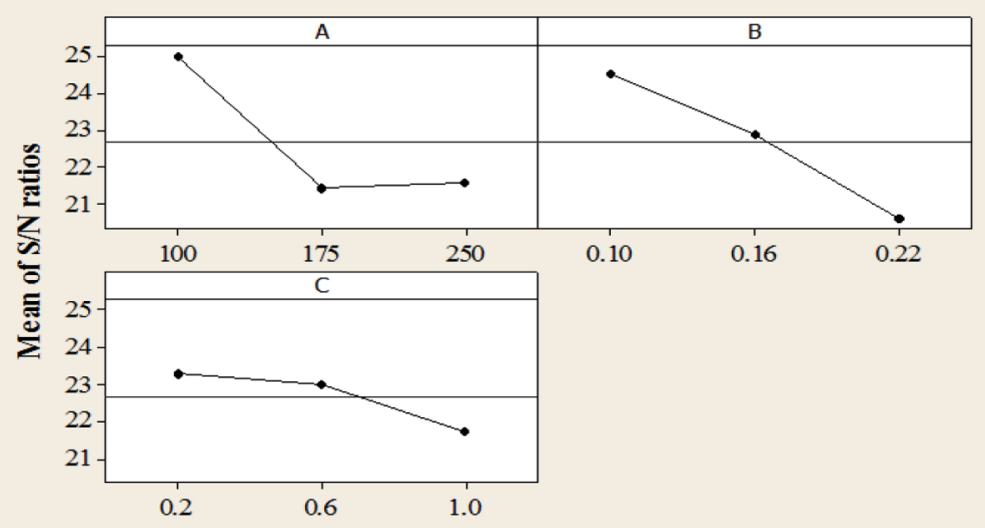

Signal-to-noise: Smaller is better

Fig. 5. Main effect plot for flank wear 


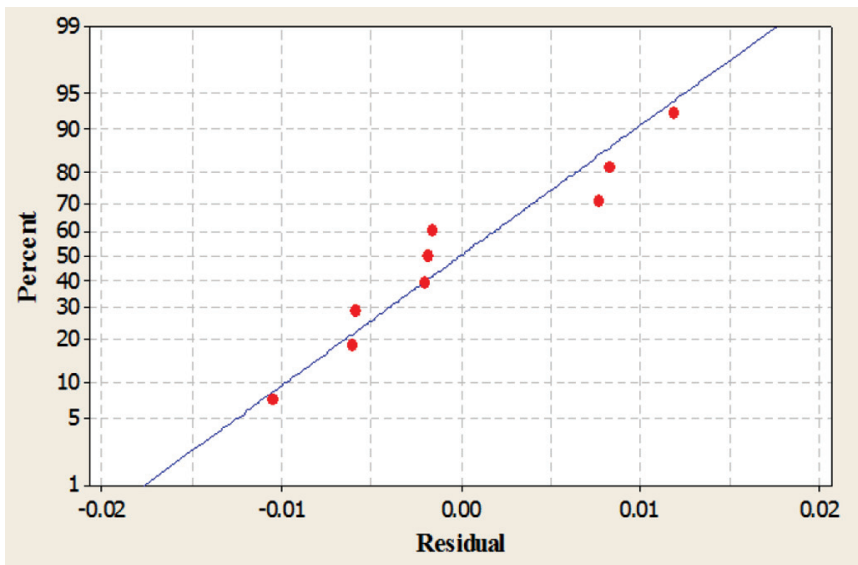

Fig. 6. Normal probability plot of the residuals for flank wear

The final regression equation for flank wear in terms of actual factor is given below:

$$
\mathrm{VB}_{\mathrm{B}}=-0.0034+0.000174 A+0.266 B+0.0110 C
$$

The ANOVA results for regression model are presented in Table 6 which reveals that the regression model for flank wear (Eqn. (3)) is significant as $\mathrm{P}$-value is less than 0.05 . In addition, the value of the term $\mathrm{R}^{2}$ (known as coefficient of determination), which is usually adopted to judge the adequacy of regression model developed, is $85.3 \%$, which means that $85.3 \%$ variation in the value of $\mathrm{VB}_{\mathrm{B}}$ is explained by the variation in the cutting parameters selected in this study.

Table 6 .

ANOVA results for regression model

\begin{tabular}{|l|c|c|c|c|c|}
\hline \multicolumn{1}{|c|}{ Source } & DF & SS & MS & F & P \\
\hline Regression & 3 & 0.00266 & 0.00088 & 9.66 & 0.016 \\
\hline Linear & 3 & 0.00266 & 0.00088 & 9.66 & 0.016 \\
\hline Residual Error & 5 & 0.00045 & 0.00009 & & \\
\hline Total & 8 & 0.00312 & & & \\
\hline S $=0.00958336$ \\
\hline PRESS $=0.00120764$ \\
\hline R-Sq $=85.3 \%$ \\
\hline R-Sq(adj) $=76.5 \%$ \\
\hline R-Sq(pred) $=61.30 \%$ \\
\hline
\end{tabular}

Figure 7 shows a comparison between the actual values and predicted values of the tool flank wear obtained from Eqn. (3). It is evident from Fig. 7 that 
the predicted values and the experimental values are very close to each other and thus, it shows significance of the model developed.

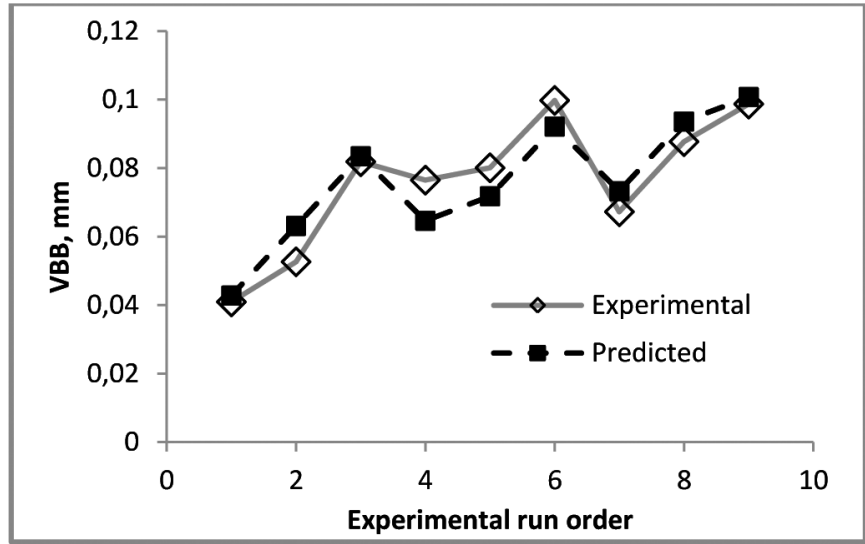

Fig. 7. Measured and predicted values of $\mathrm{VB}_{\mathrm{B}}$

\subsection{Tool Wear under Wet Condition}

The results of the tool wear study, performed in dry condition, presented in Table 3, reveal that the maximum tool flank wear $(0.09975 \mathrm{~mm})$ occurs when machining is done with cutting speed at $175 \mathrm{~m} / \mathrm{min}$, feed rate at 0.22 $\mathrm{mm} / \mathrm{rev}$, and depth of cut at $0.6 \mathrm{~mm}$ i.e. for experimental run 6 . Thus, the level of machining parameters for experimental run 6 was typically worst for the tool flank wear and therefore, the machining was performed over the same machining length i.e. $300 \mathrm{~mm}$ at these levels of the machining parameters under wet condition using the Castrol oil (brand: clearedge 6510) as cutting fluid. After machining, the flank wear was measured and its value was found to be $0.0526 \mathrm{~mm}$. On comparing the flank wear under dry condition $(0.09975$ $\mathrm{mm}$ ) with that of the wet condition $(0.0526 \mathrm{~mm})$, it is observed that the flank wear is less and $47.27 \%$ reduction in tool wear is obtained in wet machining condition. Thus, it may be concluded that wet machining helps in reducing the tool wear and thereby improves the tool life. In addition, the volume of cutting fluid consumed during machining was also measured and it was found to be $4.76 \mathrm{ml} / \mathrm{s}$.

\subsection{Machining Performance with a Micro-Channel Tool Insert}

One of the objectives of the present research is to explore the machining performance by employing a newly developed tool insert with a micro-channel. The procedure for cutting micro-channel is described in section 2.3. It is 
expected that this provision will reduce the cutting forces, improve the surface finish, dissipate heat effectively from the cutting zone, result in the utilisation of minimum possible quantity of the cutting fluid and hence, saving the energy required to operate the cutting fluid delivery system etc. In addition, several other indirect benefits such as reduction in the consumption of cutting fluid and associated emissions, lessening in the potential disadvantages owing to the use of cutting fluid in the conventional manner etc. may also be derived. The performance of the tool with micro-channel was evaluated in terms of tool wear, saving in cutting fluid quantity, and energy saving and they are discussed in the following sections.

\subsection{Wear of the Tool with Micro-Channel (TWMC) and Saving in the Quantity of the Cutting Fluid}

Machining was performed over a machining length of $300 \mathrm{~mm}$ using the tool with micro-channel at the same level of machining parameters that produced maximum flank wear in the dry condition. During machining, the cutting fluid was directed at the tool-chip interface through the microchannel. After machining, the flank wear was measured and it was found to be $0.051 \mathrm{~mm}$. This shows that the flank wear of the TWMC is substantially less as compared to both the flank wear of the tool used in dry and wet conditions. The flank wear of the tool with micro-channel is observed to be reduced by $48.87 \%$ and $3.04 \%$ as compared to dry and wet machining respectively. Improvement in the tool life is achieved because the microchannel enables direct delivery of the cutting fluid at the tool-chip interface and in the vicinity of cutting edge which substantially reduces friction at the rake and also the temperature prevailing in the cutting edge. Thus, the tool cutting edge is less hot and it is bound to wear less leading to increased tool life. Figure 8 shows the image of worn out tool inserts with micro-channel which reveals that no chipping and catastrophic failure of cutting edge of the tool insert. However, Fig. 8 reveals wear at the tool tip due to abrasion. In addition, the tool wear is found to remain within the recommended limit of $0.3 \mathrm{~mm}$. Moreover, the volume of the cutting fluid consumed during machining length of $300 \mathrm{~mm}$ is $5.9524 \cdot 10^{-7} \mathrm{~m}^{3} / \mathrm{s}$ whereas, the volume of the cutting fluid consumed for the same machining length with a tool without micro-channel is $4.7619 \cdot 10^{-6} \mathrm{~m}^{3} / \mathrm{s}$. This clearly indicates that the use of tool with micro-channel substantially reduces the consumption of cutting fluid as well and the saving is about $87.5 \%$. Thus, relatively low quantity of the cutting fluid is required with the employment of this tool which might result in less spattering and wastage of the cutting fluid, less corrosion of the machine parts, less damage to the environment in terms adding liquid and 
gaseous affluent to the environment and economical machining and probably all these will lead to green technology.

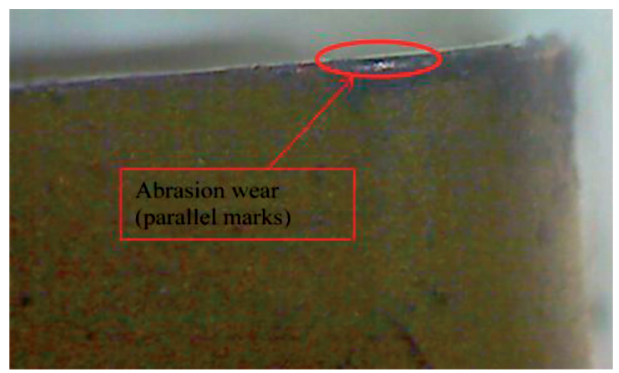

Fig. 8. Images of flank wear for tool with micro-channel

\subsection{Energy Saving}

The energy consumption and environmental impact of the cutting process has become an important topic in the recent times. All the energy requirements during machining are mainly derived from the main drive belt which includes all movement of movable parts, energy requirements for cutting and fluid supply. Among several strategies to reduce the power, researchers have used optimising process parameters [25]. In the present investigation, a saving in the fluid pumping power requirement has been estimated. The theoretical hydraulic power that is consumed in delivering the fluid to the cutting can be estimated using the principles of fluid mechanics. The hydraulic power is calculated based on height $(z)$, flow rate $(Q)$, and density $(\rho)$ as:

$$
\text { Theoretical Power }=746 \times \Delta z[\mathrm{~m}] \times Q\left[\frac{\mathrm{m}^{3}}{\mathrm{~s}}\right] \times \rho\left[\frac{\mathrm{kg}}{\mathrm{m}^{3}}\right]
$$

Using Eqn. (4), the power consumed in machining a length of $300 \mathrm{~mm}$ under wet condition with a tool without micro-channel was calculated and it was found to be $11.14 \mathrm{~J} / \mathrm{s}$. Further, the machining time for machining the same $300 \mathrm{~mm}$ length was observed to be $94 \mathrm{~s}$. Thus, the energy consumed during machining is $1.05 \mathrm{~kJ}$.

Similarly, the power consumed in machining a length of $300 \mathrm{~mm}$ using micro-channel cooling was also calculated and it was found to be $1.4 \mathrm{~J} / \mathrm{s}$ resulting in energy consumption of $131.6 \mathrm{~J}$. Thus, it is found that the use of the newly developed multilayer coated carbide tool insert with micro-channel in hard turning for machining a length of $300 \mathrm{~mm}$ results in an energy saving of about $87.5 \%$ as compared to the case when a tool without micro-channel is employed. 


\section{Conclusion}

This paper presents a study that deals with the experimental investigation pertaining to turning of AISI 52100 hard alloy steel under varying levels of cutting speed, feed rate, and depth of cut using multilayer coated carbide insert. Taguchi $\mathrm{L}_{9}$ orthogonal array is applied to study the effect of cutting parameters on the flank wear of the insert. Based on the results of the investigation, following conclusions are drawn:

1. The Taguchi method is an effective and robust method that can be used to obtain optimum results with relatively lesser number of experiments, especially in situations where cost of conducting experiments is reasonably high such as in the tool wear study.

2. The optimal parametric combination for flank wear under dry condition is found to be $A_{1} B_{1} C_{1}$ i.e. cutting speed at $100 \mathrm{~m} / \mathrm{min}$, feed rate at $0.1 \mathrm{~mm} / \mathrm{rev}$ and depth of cut at $0.2 \mathrm{~mm}$ respectively.

3. From ANOVA results, cutting speed and feed rate are found to significantly affect flank wear. However, the depth of cut does not significantly affect the flank wear.

4. CVD (TiN-TiCN-AL $\mathrm{O}_{3}$-TiN) coated carbide insert exhibited a good performance during hard turning with various cutting parameters as the flank wear values are found to be well below the recommended limit of $0.3 \mathrm{~mm}$.

5. The novel approach presented in this paper to develop a tool insert with micro-channel results in substantial saving of energy and volume of cutting fluid consumed which in turn will reduce the discharge of affluent to the environment leading to a green machining process.

6. This paper provides an approach to the industry to employ a more cost effective tool material with the novel design such as the one used in the present investigation instead of expensive tool materials for hard turning.

\section{Acknowledgment}

The authors acknowledge Diyala University, Iraq and the Ministry of Higher Education and Scientific Research, Iraq for endowing with financial assistance to this research. The authors are grateful to the Jamia Millia Islamia, New Delhi, India for providing facilities for conducting experiments and measurements that are reported in this paper. 


\section{REFERENCES}

[1] Huang Y., Chou Y.K., Liang S.Y.: CBN tool wear in hard turning: a survey on research progresses. International Journal of Advanced Manufacturing Technology, 2007; Vol. 35, No. 5-6, pp. 443-453.

[2] Aouici H., Yallese M.A., Chaoui K., Mabrouki T., Rigal J.F.: Analysis of surface roughness and cutting force components in hard turning with CBN tool: Prediction model and cutting conditions optimization. Measurement, 2012, Vol. 45, No. 3, pp. 344-353.

[3] Domenico Umbrello, Fabrizio Micari, I.S. Jawahir. (2012) The effects of cryogenic cooling on surface integrity in hard machining: A comparison with dry machining, CIRP Annals - Manufacturing Technology61(1): 103-106.

[4] Domenico U, Fabrizio M, Jawahir I.S.: The effects of cryogenic cooling on surface integrity in hard machining: A comparison with dry machining, CIRP Annals - Manufacturing Technology, 2012, Vol. 61, No.1, pp. 103-106.

[5] Ozel T., Karpat Y., Srivastava A.: Hard turning with variable micro-geometry pcBN tools. CIRP Annals - Manufacturing Technology, 2008, Vol. 57, No.1, pp. 73-76.

[6] Ozel T., Sima M., Srivastava A.K., Kaftanoglu B.: Investigations on the effects of multi-layered coated inserts in machining Ti-6Al-4V alloy with experiments and finite element simulations. CIRP Annals - Manufacturing Technology, 2010, Vol. 59, No.1, pp. 77-82.

[7] Gaitonde V.N., Karnik S.R., Figueira L., Davim J.P.: Machinability investigations in hard turning of AISI D2 cold work tool steel with conventional and wiper ceramic inserts. Int. Journal of Refractory Metals \& Hard Materials, 2009b, Vol. 27, No. 4, pp. 754-763.

[8] Aslantas K., Ucunb I., Cicek A.: Tool life and wear mechanism of coated and uncoated Al2O3/TiCN mixed ceramic tools in turning hardened alloy steel. Wear, 2012, Vol. 274-275, pp. 442-451.

[9] Klimenko S.A., Manokhin A.S., Mel'niichuk Y.A.: Wear and life of tools with inserts from CBN based polycrystalline superhard materials in the finish turning of hardened steels at heavy feeds. Journal of Superhard Materials, 2012, Vol. 34, No. 1: 49-55.

[10] Mandal N., Doloi B., Mondal B.: Machining parameters optimization of developed yttria stabilized zirconia toughened alumina ceramic inserts while machining AISI 4340 steel. World Academy of Science, Engineering and Technology 2012, Vol. 6, pp. 3-27.

[11] Darshan C., Singh L., Sethi A.P.S.: Analysis and optimization of ceramic cutting tool in hard turning of EN-31 using factorial design. International Journal of Mechanical and Industrial Engineering, 2012, Vol. 1, No. 4, pp. 49-54.

[12] Dogra M., Sharma V.S., Sachdeva A., Suri N.M.: Finish hard turning of continuous and interrupted surfaces with cubic boron nitride $(\mathrm{CBN})$ and coated carbide tools. Materials and Manufacturing Processes, 2012, Vol. 27, No. 5, pp. 523-530.

[13] Saini S., Ahuja I.S., Sharma V.S.: Influence of cutting parameters on tool wear and surface roughness in hard turning of AISI H11 tool steel using ceramic tools. International Journal of Precision Engineering And Manufacturing, 2012, Vol. 13No. 8, pp. 1295-1302.

[14] Chinchanikar S., Choudhury S.K.: Investigations on machinability aspects of hardened AISI 4340 steel at different levels of hardness using coated carbide tools. Int. Journal of Refractory Metals and Hard Materials, 2013, Vol. 38, pp. 124-133.

[15] El Hakim M.A., Abad M.D., Abdelhameed M.M., Shalaby M.A., Veldhuis S.C.: Wear behavior of some cutting tool materials in hard turning of HSS. Tribology International, 2011, Vol. 44, No.10, pp. 1174-1181.

[16] Suresh R., Basavarajappa S., Samuel G.L.: Some studies on hard turning of AISI 4340 steel using multilayer coated carbide tool. Measurement, 2012a, Vol. 45, No. 7,pp. 1872-1884.

[17] Suresh R., Basavarajappa S., Gaitond V.N., Samuel G.L.: Machinability investigations on hardened AISI 4340 steel using coated carbide insert. Int. Journal of Refractory Metals and Hard Materials, 2012b, Vol. 33, pp. 75-86. 
[18] Ebrahimi A., Moshksar M.M.: Evaluation of machinability in turning of microalloyed and quenched-tempered steels: Tool wear, statistical analysis, chip morphology. Journal of materials processing technology, 2009, Vol. 209, No. 2, pp. 910-921.

[19] Zaghbani I., Songmene V., Kientzy G.: Evaluation of sustainability of mould steels based on machinability data. Int. J. Machining and Machinability of Materials, 2010, Vol. 7, No. 1/2, pp. 58-81.

[20] Sahoo A.K., Pradhan S.: Modeling and optimization of Al/SiCp MMC machining using Taguchi approach. Measurement, 2013, Vol. 46, pp. 3064-3072.

[21] Sahoo A.K., Sahoo B.: Performance studies of multilayer hard surface coatings (TiN/TiCN/ $\mathrm{Al}_{2} \mathrm{O}_{3} / \mathrm{TiN}$ ) of indexable carbide inserts in hard machining: Part-I (An experimental approach). Measurement, 2013, Vol. 46, No. 8, pp. 2868-2884.

[22] Mandal N., Doloi B., Mondal B., Das R.: Optimization of flank wear using Zirconia Toughened Alumina (ZTA) cutting tool: Taguchi method and Regression analysis. Measurement, 2011, Vol. 44, No. 10, pp. 2149-2155.

[23] Kivak T.: Optimization of surface roughness and flank wear using the Taguchi method in milling of Hadfield steel with PVD and CVD coated inserts. Measurement, 2014, Vol. 50, pp. 19-28.

[24] Selvaraj D.P.: Chandramohan P, Mohanraj M. Optimization of surface roughness, cutting force and tool wear of nitrogen alloyed duplex stainless steel in a dry turning process using Taguchi method. Measurement, 2014, Vol. 49, No. 205-215.

[25] Mori, M., Fujishima, M., Inamasu, Y., Oda, Y.: A study on energy efficiency improvement for machine tools. CIRP Annals - Manufacturing Technology, 2011, Vol. 60, No. 1, pp. 145-148.

\section{Nowe podejście do poprawy osiągów w toczeniu na twardo przy użyciu wielowarstwowej płytki z ceramiki narzędziowej}

\section{Streszczenie}

W pracy przedstawiono badania nad zużyciem krawędzi skrawającej wielowarstwowej płytki z ceramiki narzędziowej (TiN/TiCN/ $\left.\mathrm{Al}_{2} \mathrm{O}_{3} / \mathrm{TiN}\right)$ w toczeniu twardym na sucho. Badano także zużycie krawędzi skrawającej w warunkach toczenia na mokro. Nowatorskim rozwiązaniem było zastosowanie mikrokanału w płytce skrawającej, przez który płyn smarny dostarczany jest bezpośrednio do styku między narzędziem i wiórem. Uzyskany tą drogą niższy poziom parametrów skrawania zapewnia minimalne zużycie krawędzi skrawającej, na które w istotny sposób wpływają prędkość skrawania i szybkość posuwu. W porównaniu do warunków toczenia na sucho i na mokro, zastosowanie mikrokanału zmniejsza zużycie krawędzi skrawającej o odpowiednio 48,87\% i 3,04\%. Narzędzie z mikrokanałem zapewnia także oszczędność zużycia płynu smarnego i energii o ok. 87,5\%. 